\title{
Lean Six Sigma in Academic Institutions-UK vs. Rest of the World
}

\author{
Stephen Anthony \\ Email: steve@lighthouseconsultants.co.uk \\ Jiju Antony, $\mathrm{PhD}$ \\ Email: J.Antony@hw.ac.uk
}

School of Management and Languages, Heriot-Watt University, Scotland, UK

\begin{abstract}
Purpose: The main purpose of this paper is to illustrate examples of the current maturity of universities both in the UK and abroad when implementing a continuous improvement programme or change agenda using techniques such as Lean Six Sigma.
\end{abstract}

Design/Methodology/Approach: 21 UK universities and 17 International Universities have been identified and targeted with a questionnaire to research their approaches to implementing a continuous improvement programme / change agenda. The results have been collated and presented in two sections - the first being overall trends, the second being detailed questionnaire responses.

Findings: This paper highlights the initial findings from 21 universities in the UK which responded to a survey and compares them with the findings from 17 international universities known to be working in the field on Lean Six Sigma. In addition, several trends have been observed from the research - and these are presented as a summary of the results.

Research Limitations/Implications: All UK universities have been targeted, with 21 respondents, followed by the contacting of 17 international universities which have attended Lean Six Sigma conferences in the last 2 years.

Practical Applications: This is the first step in building a leadership maturity model for international universities in their approach to Six Sigma

Originality/Value: This is the first attempt of its kind to map the UK university institutions approach and view of managing change using management strategies such as Lean Six Sigma.

Keywords: Academic Leadership, Leadership, Characteristics, Trends

Paper type: Conference Paper 


\section{Lean Six Sigma in Academic Institutions - The Context}

There is no denying that academic institutions are facing many challenges in todays globalised educational world with public funding cuts, commercially driven credit based curriculums, accountability, quality assurance, the student as customer, and performance based management are all key themes being wrestled with by academic leaders, (Laing and Laing 2011, Kurniawan and Puspitaningtyas 2013.) In addition, management language such as excellent academic performance, organise effectively, efficiently, sustainably, and with accountability have sneaked into the vocab of academic leaders, (Kurniawan and Puspitaningtyas 2013)

In addition universities are benchmarked evermore by outside institutions - for example the recent Times world rankings of universities ranked the University of Oxford as the first UK university to top the Times Higher Education World University Rankings in the 12-year history of the table. It knocks the five-time leader, the California Institute of Technology, into second place in the World University Rankings 2016-2017. The Times report starts with the phrase: "World University Rankings 2016-2017: Standing still is not an option"

The lists attributes Oxford's success to improved performances across the four main indicators underlying the methodology of the ranking - teaching, research, citations and international outlook. More specifically the institution's total income and research income is rising faster than its staff numbers, its research is more influential, and it has been more successful at drawing in international talent.

Universities are expected to be efficient and cost effective, flexible in their offerings while being responsive to the student expectations, (Joyce and Boyle 2013.) Leading universities in this Times list present unique challenges, because of the organisations' complexity, its multiple goals, and its traditional values - but how are universities meeting this challenge? Are they using not just the language of modern management techniques but also the methodologies of continuous improvement, such as Lean Six Sigma, to deliver real change?

This paper highlights the findings from 21 universities in the UK and a further 17 universities from across the world which responded to a survey issued in January 2016 to 172 UK institutions and 20 international institutions in January 2017. The primary role of the survey method would be to identify suitable case study candidates for future research, comparison with an international audience and a possible new maturity model for implementing Lean Six Sigma in academia. However it was expected that significant insight will come from this actual study itself.

\section{Surveys and Quantitative Research}

Quantitative research refers to the systematic empirical investigation of social phenomena via statistical, mathematical or numerical data or computational techniques. (Given, 2008) The main objective of quantitative research is to develop mathematical models, theories and/or hypotheses pertaining to certain phenomena. It is expected that the data collected from a questionnaire targeting the universities in the world which teach Lean, Six Sigma, and Lean Six Sigma should create some significant observations and identify which universities practice internally what they are delivering to an external audience.

Vogt (2010) states the aim of questionnaires is often less to discover a causal link between variables (internal validity) and more to generalize a finding from a sample to a population (external validity). The best known example is in election surveying. The population of likely voters is identified, a random sample is taken using more or less complicated sampling techniques, and respondents are asked about their voting plans - whether they intend to vote and if so, for whom. Attempting to survey samples from populations whose members are rare 
or unknown raises complicated uncertainties. One cannot very easily sample from a population when it is difficult to find or when one does not know what it is. So the first step becomes defining or identifying the population rather than sampling from it, (Vogt 2010.)

The assumption for the author is that universities which teach Lean, Six Sigma or Lean Six Sigma will potentially also be using these methods to improve their organisational performance. During the summer of 2015 the author researched 172 UK universities to identify which of them offered Lean Six Sigma training as a standalone course or part of another engineering programme. For example the ISRU unit at Newcastle University in the UK offers public and in-house courses on Lean Six Sigma and the use of industrial statistics to solve process problems (http://www.isru.ncl.ac.uk/lean-six-sigma.)

Of the 172, 118 appeared to have no recognisable Lean Six Sigma programme of module, leaving a population of 54 to approach. However the contact details remain of the 118 and it was decided that in January 2016 all 172 institutions would be contacted electronically via the Vice Chancellors Office and requested to complete a simple questionnaire. The questions identified will need to be grounded in research, for example any question relating to the interactions of leadership and successful Lean Six Sigma implementation would relate back to the work of Mayo and Nohria (2005) in relation to the importance of complex interactions in leadership success. Using the findings from the author's earlier work each question is supported by a reference and piece of literature. Table 1 below highlights the 10 questions issued to the 172 institutions. The author expected to gain significant insight into the process of implementing Lean and Six Sigma in academic institutions since several organisations exist within universities to drive continuous improvement. For example the Lean HE Hub started by Coventry University, The Process Improvement Unit at the University of Sheffield and the Business Improvement Team at Aberdeen University. It is worth noting though that no pure Six Sigma business improvement teams appear to be operating in UK universities at this time and all process improvement activity appears to have developed from the Lean school of thought. This maybe down to the fact that Lean Thinking was observed and developed by academics initially, or simply that Lean is less perceived to be less complex and easier to implement.

A year later 20 international universities where contacted and 17 responses where gleaned allowing a comparison to be made between the UK and those universities in the rest of the world which were publicising Lean Six Sigma activity at academic conferences and in papers.

Within the UK universities in Scotland, England and Wales responded to the survey. From the rest of the world, (RoW,) Greece, , India, Macedonia, Malaysia and the USA all submitted valid responses. 


\begin{tabular}{|c|c|}
\hline Question: & Grounded In Research \\
\hline $\begin{array}{l}\text { 1. Are you currently undergoing, or planning to implement, } \\
\text { a continuous improvement programme / change agenda } \\
\text { within the university? }\end{array}$ & $\begin{array}{l}\text { Maleyeff (2014), Mehmood et } \\
\text { al 2012, Shahmandi et al } \\
\text { 2011, Temponi (2005) }\end{array}$ \\
\hline $\begin{array}{l}\text { 2. What is your objective, or reason for undergoing this } \\
\text { continuous improvement programme / change agenda? }\end{array}$ & $\begin{array}{l}\text { Radnor and Walley (2008), } \\
\text { Jenicke et al } 2008\end{array}$ \\
\hline $\begin{array}{l}\text { 3. How will success of this continuous improvement } \\
\text { programme / change agenda be measured? }\end{array}$ & $\begin{array}{l}\text { Manville et al (2012), Snee } \\
\text { (2011), Siddique et al 2011, } \\
\text { Sakthivel (2007) }\end{array}$ \\
\hline $\begin{array}{l}\text { 4. Are you using a methodology, philosophy or structured } \\
\text { approach, such as Lean or Six Sigma, for this continuous } \\
\text { improvement activity - if so what kind of approach are } \\
\text { you using? }\end{array}$ & $\begin{array}{l}\text { Hines and Lethbridge 2008, } \\
\text { Heuvel, 2005, Antony (2014), } \\
\text { Jenicke and Holmes (2008) }\end{array}$ \\
\hline $\begin{array}{l}\text { 5. Are you utilising outside expertise to assist in the } \\
\text { continuous improvement programme / change agenda? }\end{array}$ & $\begin{array}{l}\text { Kurniawan and } \\
\text { Puspitaningtyas (2013), Kumi } \\
\text { and Morrow (2006) }\end{array}$ \\
\hline $\begin{array}{l}\text { 6. Does the higher educational institution have a history of } \\
\text { successful projects, change programmes or continuous } \\
\text { improvement activity using structured approaches such } \\
\text { as Lean, Six Sigma or Lean Six Sigma or your chosen } \\
\text { approach? }\end{array}$ & $\begin{array}{l}\text { Azis and Osada (2010), } \\
\text { Antony et al (2012) }\end{array}$ \\
\hline $\begin{array}{l}\text { 7. Who is leading this continuous improvement programme } \\
\text { / change agenda and where do they sit within the } \\
\text { organisation? }\end{array}$ & $\begin{array}{l}\text { Snee's (2007), Snee and Hoerl } \\
(2002)\end{array}$ \\
\hline $\begin{array}{l}\text { 8. Who is responsible at board or executive level for } \\
\text { strategy and vision of the continuous improvement / } \\
\text { change agenda? }\end{array}$ & $\begin{array}{l}\text { Collins (2001), Loethen } \\
\text { (2008), Bryman (2009) }\end{array}$ \\
\hline $\begin{array}{l}\text { 9. What characteristics, competencies, knowledge, skills } \\
\text { and behaviours within the leader/leadership team were } \\
\text { particular required for this programme to be given the } \\
\text { best chance of success? }\end{array}$ & $\begin{array}{l}\text { Mayo and Nohria (2005), } \\
\text { Emiliani (2013) }\end{array}$ \\
\hline $\begin{array}{l}\text { 10. How will the institution sustain any gains and successes } \\
\text { made through the continuous improvement programme / } \\
\text { change agenda? }\end{array}$ & $\begin{array}{l}\text { Antony et al (2012), Jenicke } \\
\text { and Holmes (2008) }\end{array}$ \\
\hline
\end{tabular}

Table 1. Questions Issued Electronically to 172 Institutions in January 2016 and a Further 20 in January 2017 


\section{The Trends and Key Findings - The UK vs. Rest of the World Perspective}

Before explaining the specific findings, several clear trends have emerged from this research:

3.1 The main reason for embarking on a programme of continuous improvement programme / change agenda within a UK university was to improve the staff and student experience within the institution - however this is not born out in the detail since many of the improvement programmes are focused on administrative rather than teaching based processes. For the RoW the key drivers were explicit cost reduction challenges or outside accreditation and recognition.

3.2 Where measures of success do exist in the UK the national student survey forms the main measure of success - however this appears to be a very simplistic approach to measuring success. Any survey suffers from the bias of the most recent history skewing the results. For example if there has been a recent pay cut to staff and then an employee survey is released enquiring about staff engagement in Lean Six Sigma it is likely to gain negative results, even if the previous 11 months have demonstrated successful projects. The RoW rely heavily on internal and external surveys as well, however there is also evidence of strong project management and time management based performance indicators.

3.3 Virtually all improvement activity is Lean Thinking based, rather than Six Sigma, Lean Six Sigma, Systems Thinking, or other business improvement approaches. These Lean Thinking approaches are almost universally applied to administrative based processes - this may be due to Lean having significant roots in several universities, whereas Six Sigma appears to have struggled to gain academic acceptance beyond a few institutions and courses, for example KAUST in Saudi Arabia and Herriot-Watt in the UK.

3.4 Typically UK universities are using a team based approach, led by a CI champion or project manager to implement the continuous improvement programme / change agenda. The RoW tend to deploy using a more senior individual to lead the programme. In addition several institutions are using external support from consultancies to supplement their internal resource on a typical $80 \%$ internal $/ 20 \%$ external mix in the UK and $65 \%$ internal $/ 35 \%$ external in the RoW - there appears to be a reluctance to use internal academic expertise within the UK compared to the RoW, relying on outside consultants or administrative managers within the institutions studied. This reluctance is clearly also re-enforcing the fact that all programmes studied are administratively based in the UK, whereas there is some evidence that Lean Six Sigma has moved beyond administrative functions in the RoW.

3.5 Over $60 \%$ of respondents have never embarked on a continuous improvement programme / change agenda before starting this one, with only one institution in the UK contacting another university for assistance and guidance in implementing Lean - it is interesting that these leaders have not recognised the high volume of capital project and construction activity within their institutors and have not realised that, for example, building new student accommodation or facilities is an improvement activity, whereas several RoW respondents cited construction and commissioning projects as sources of learning when implementing a continuous improvement / change agenda.

3.6 Within the UK the institution Registrar appears to both lead the programme at operational level and at board level in most circumstances - again this re-enforces the role played by Lean Six Sigma to be one centred within the administrative rather than teaching or research fields. A more varied response existed within the RoW with leadership of the programme typically sitting at a director level, and governance sitting with the board. 
3.7 There is no real evidence in the UK to support ongoing sustainability strategies or tools beyond additional training and current performance management techniques - sustainability challenges have plagued manufacturing companies for decades, however organisations try, through the use of Poke Yoke, SPC, Control Plans, Auditing, Process Drift Measurement, and Standard Operating Procedures etc, to build long term control and stability into their processes. The lack of any tools being reference in this study is a concern. There is some evidence of sustainability within the RoW, however this was not as strong as expected.

3.8 Finally within the UK a lack of continuous improvement maturity exists, demonstrated by the answers of some of the questions given, with several answers relating to simple CI activity, such as process mapping, and the main knowledge, skills and behaviours recorded were "basic project management skills", rather than, for example, leadership, root cause analysis, design of experiments, and data analysis skills - much has been written in academic journals on how organisations can successfully implement Lean Six Sigma and leadership is always at the top of the critical success factors of any industrial organisation trying to implement Lean Six Sigma. It appears that academic institutions in the UK have a long way to go before they can truly claim to be Lean, or Six Sigma. There is evidence that the RoW is slightly ahead of the UK, however not by as much as first thought. Within the RoW the USA appears to be the furthest ahead with regards to the use of Lean Six Sigma.

\section{Specific Findings}

From a population of 192 (172 UK, 20 RoW) institutions, 37 universities and 1 college responded to the survey

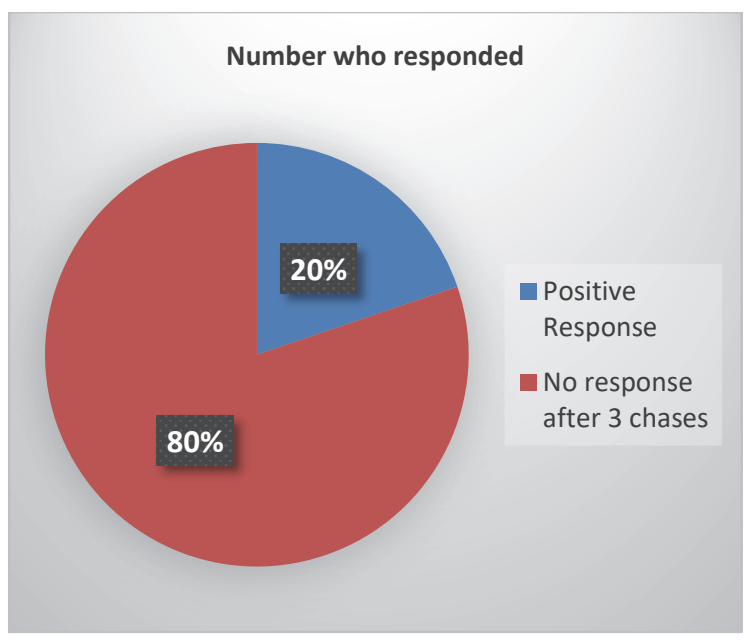

3.1 Question 1: Are you currently undergoing, or planning to implement, a continuous improvement programme / change agenda within the university? 


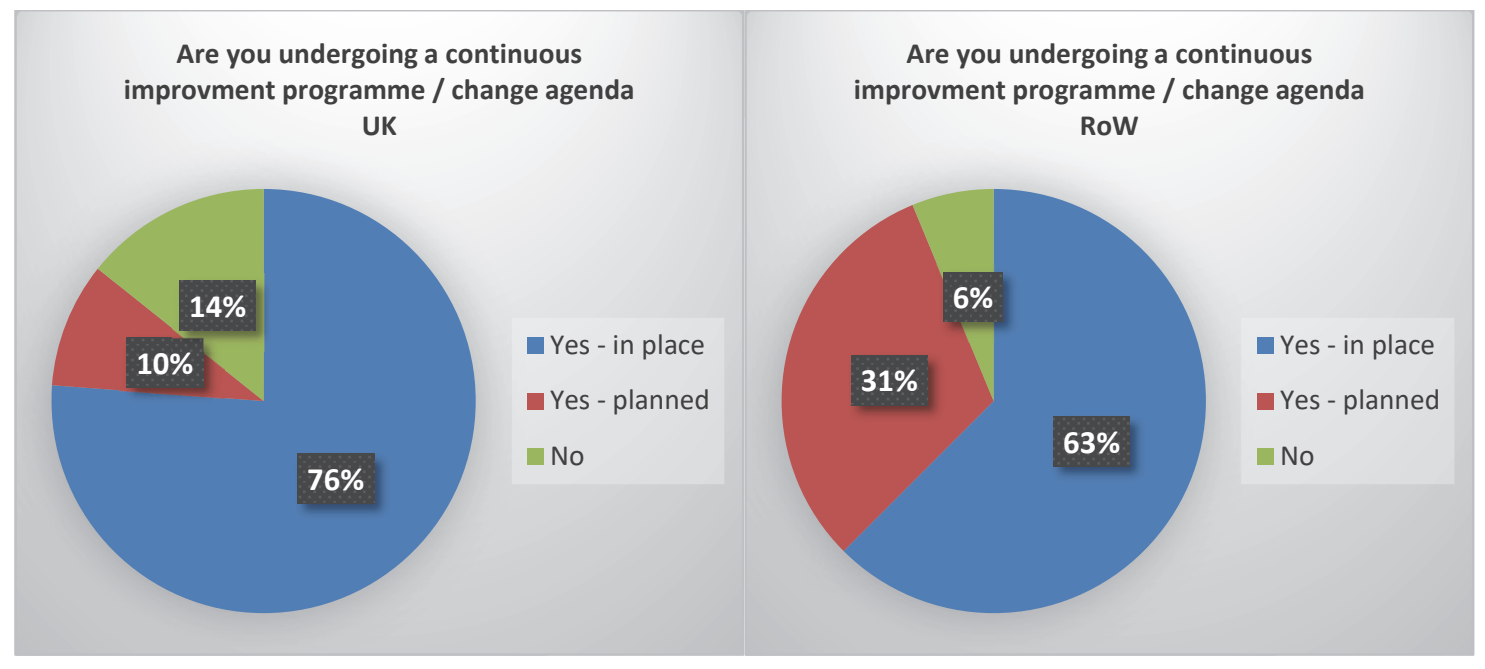

3.2 Question 2: What are your objectives, or reasons, for undergoing this continuous improvement programme / change agenda?



3.3 Question 3: How will success of this continuous improvement programme / change agenda be measured? 


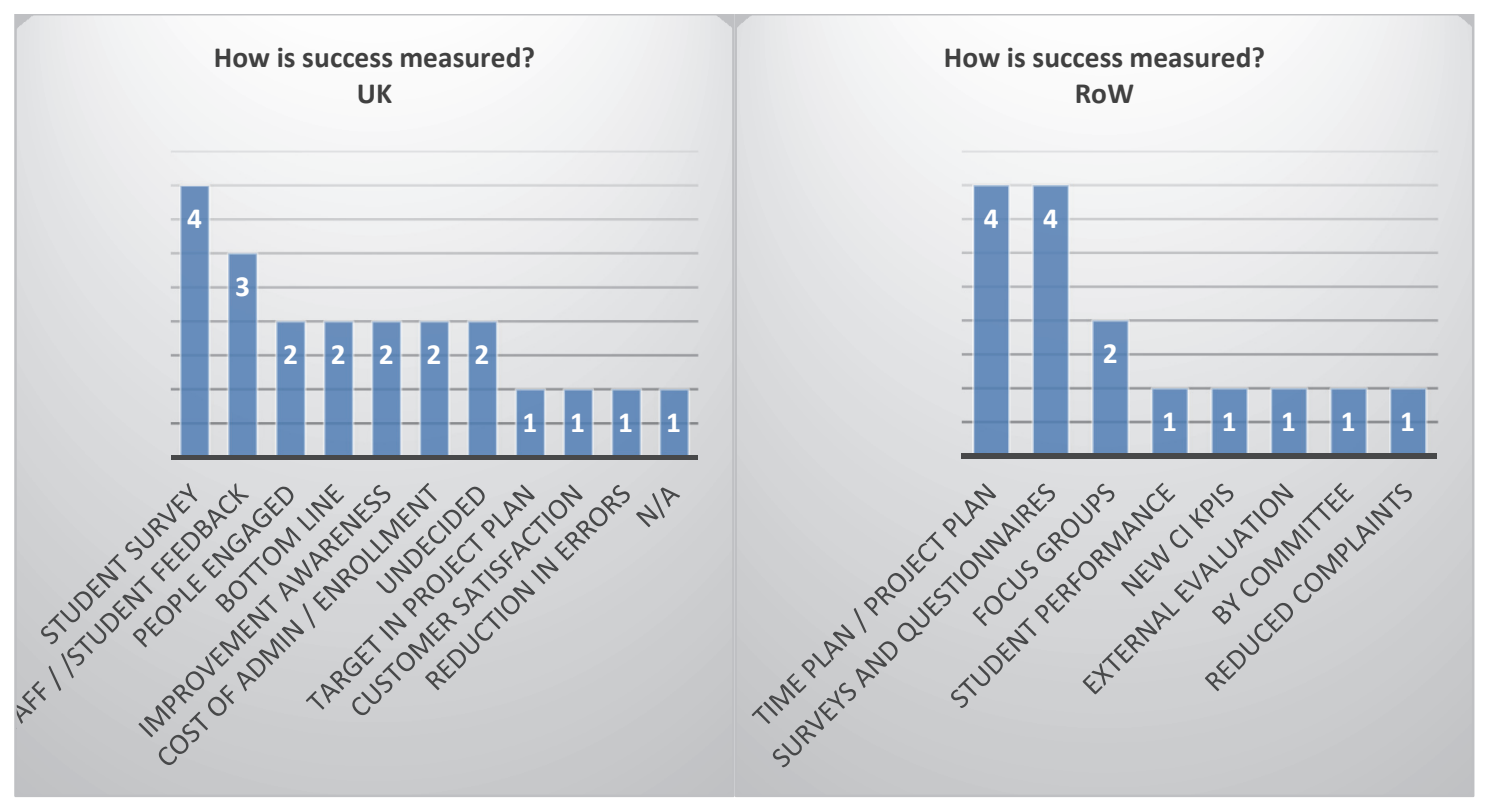

3.4 Question 4: Are you using a methodology, philosophy, or structured approach, such as Lean or Six Sigma, for this continuous improvement programme / change agenda?

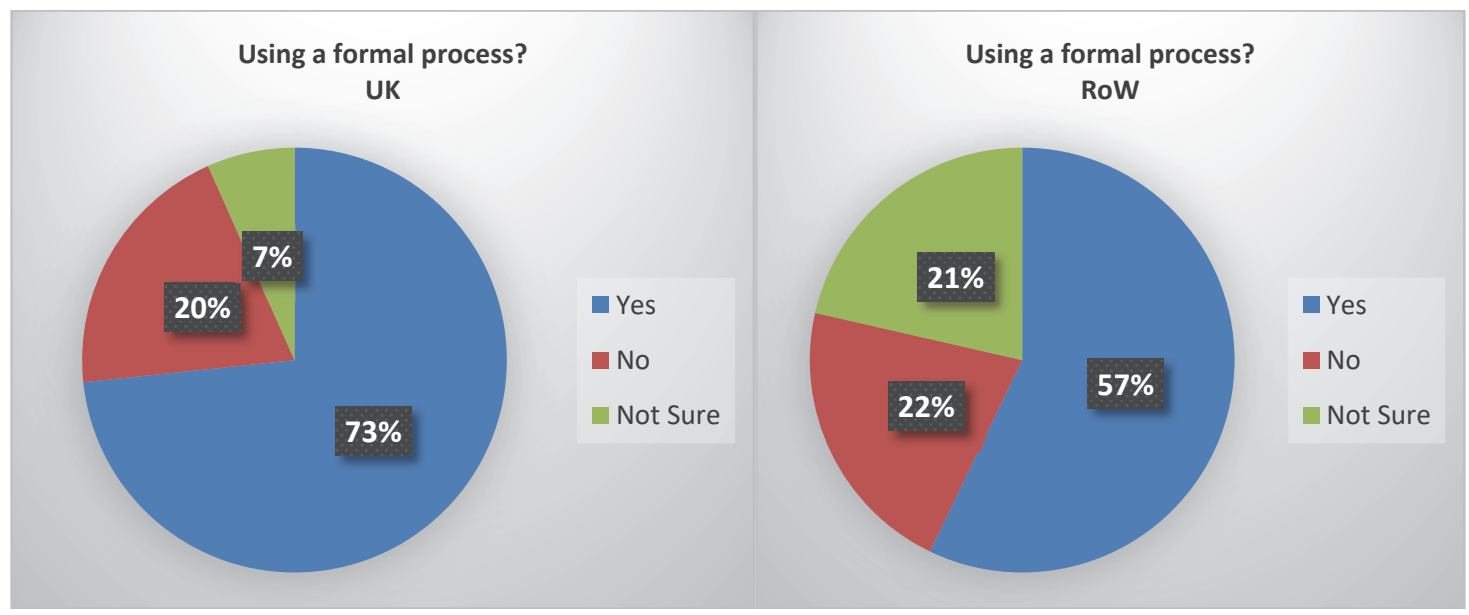




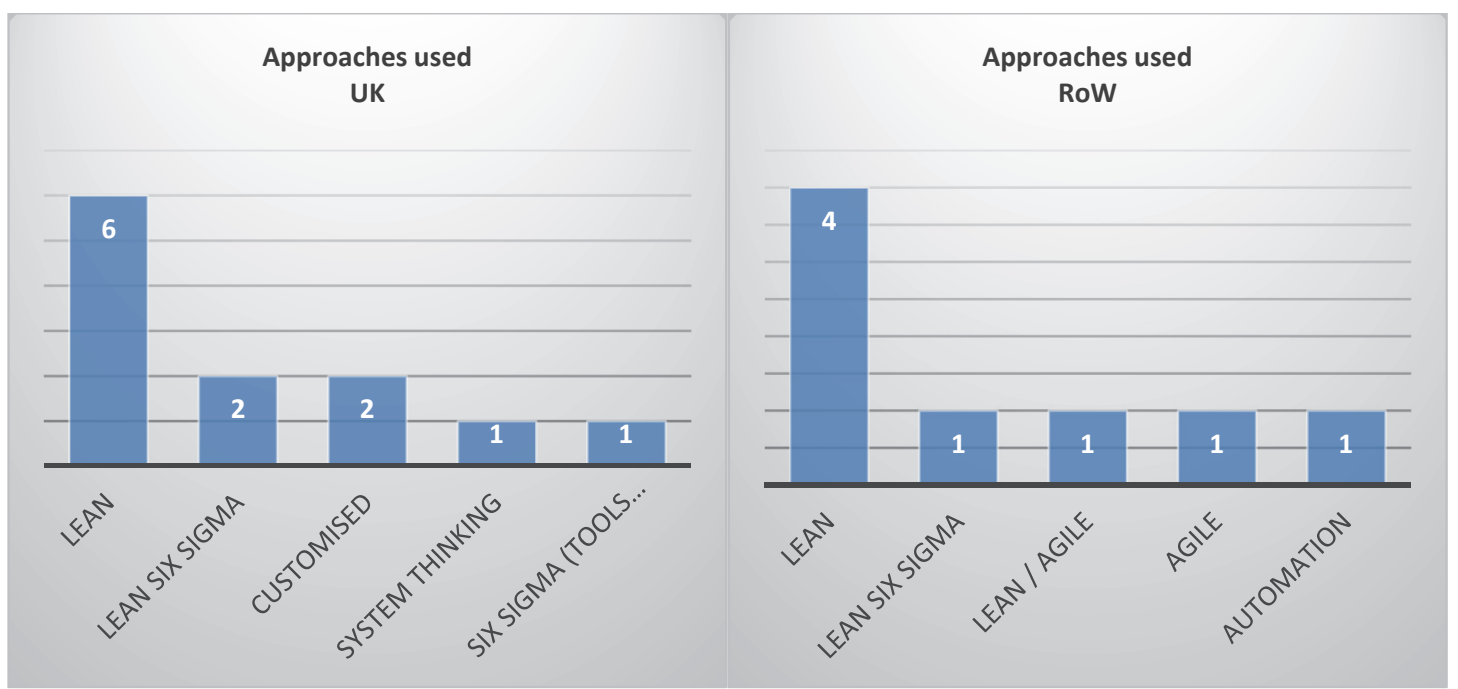

3.5 Question 5: Are you utilizing external or internal expertise to assist in your continuous improvement programme / change agenda?

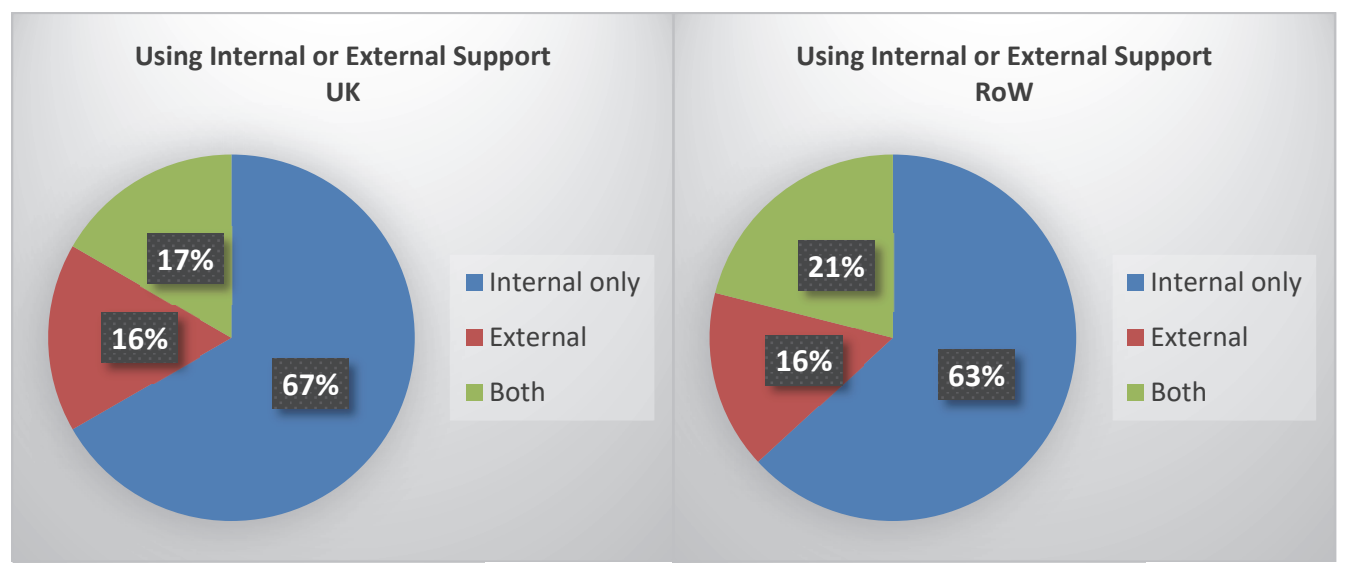

For the UK 3 main external sources were:

- Large consultancy firms

- Small consultancy firms

- Specialist units form other universities

Fir the RoW the 2 main external sources were:

- External auditors

- Large consultancy

For universities that deployed both the ratio of internal to external support was $80 \%$ internal $20 \%$ external for the UK and $65 \%$ internal and $35 \%$ external for the RoW. 


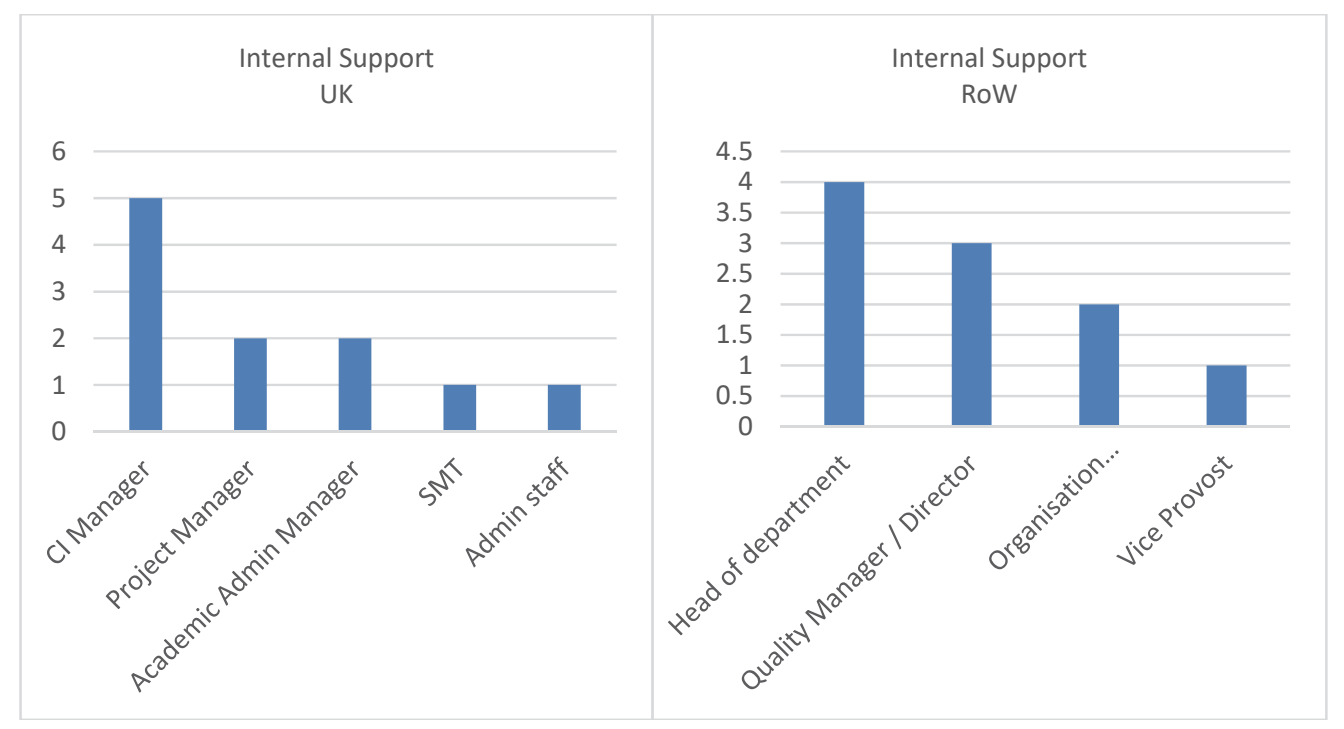

3.6 Question 6: Does the university have a history of successful continuous improvement programmes / change agendas using structured approaches such as Lean or Six Sigma?

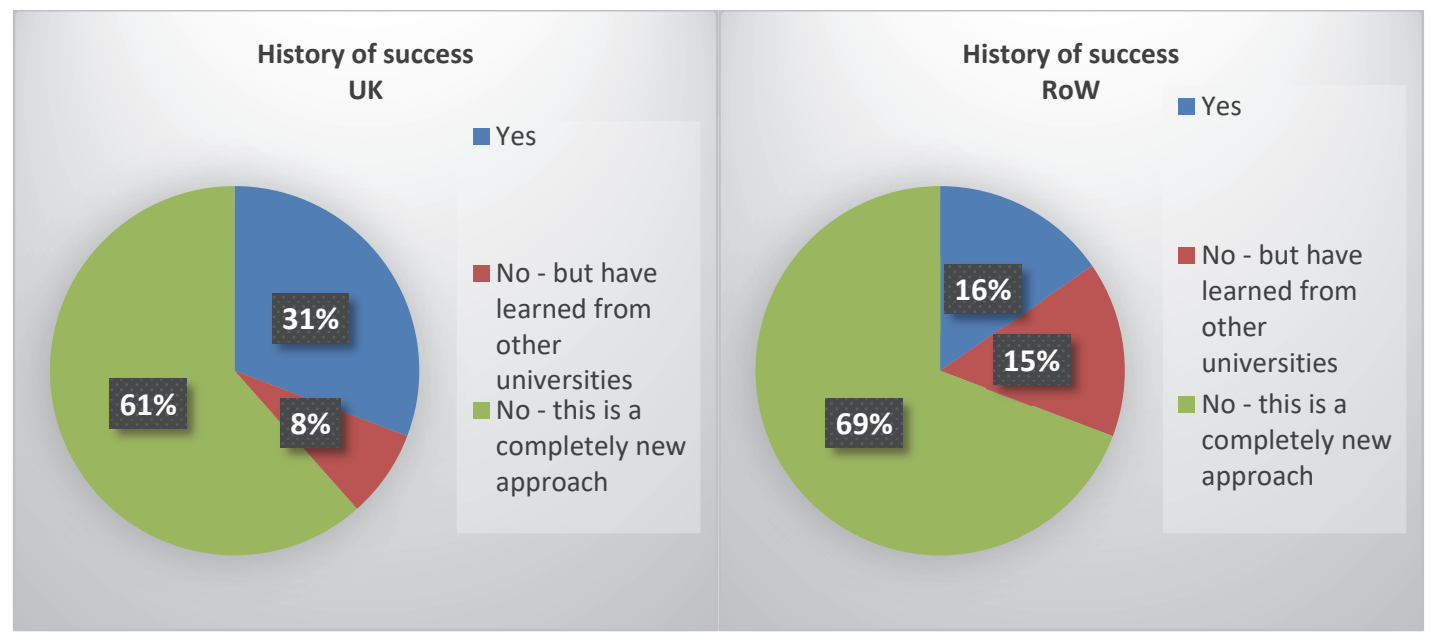

Key learning outcomes from the UK:

- The need for staff to own the change

- Cross departmental learning to reduce silo thinking

- Build Lean Reviews into all technical specifications and project initiation documents

- Benchmark the project using other techniques such as EFQM

- Learn by visiting other universities further along the journey

Key learning outcomes from the RoW:

- The importance of data collection and key performance metrics

- The importance of learning from other change programmes within the institution for example construction and commissioning projects

- The power of learning from other organisations to help facilitate change

- The use of internal experts to facilitate change rather than external expertise 
3.7 Question 7: Who is leading this continuous improvement programme / change agenda and where do they sit within the organisations' hierarchy?

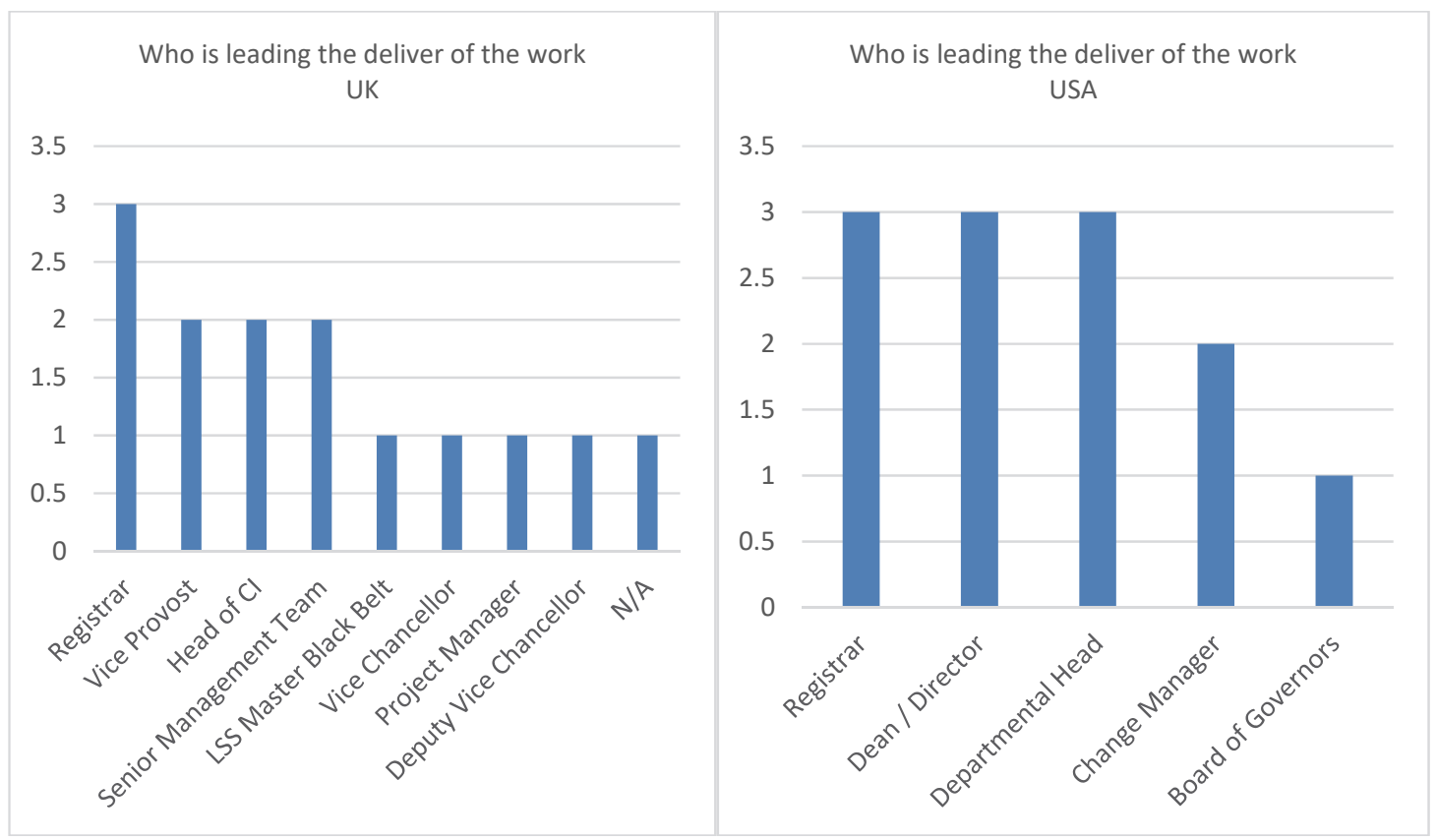

3.8 Question 8: Who is responsible at board or executive level for the strategy, vision and senior management oversight of the continuous improvement programme / change agenda?

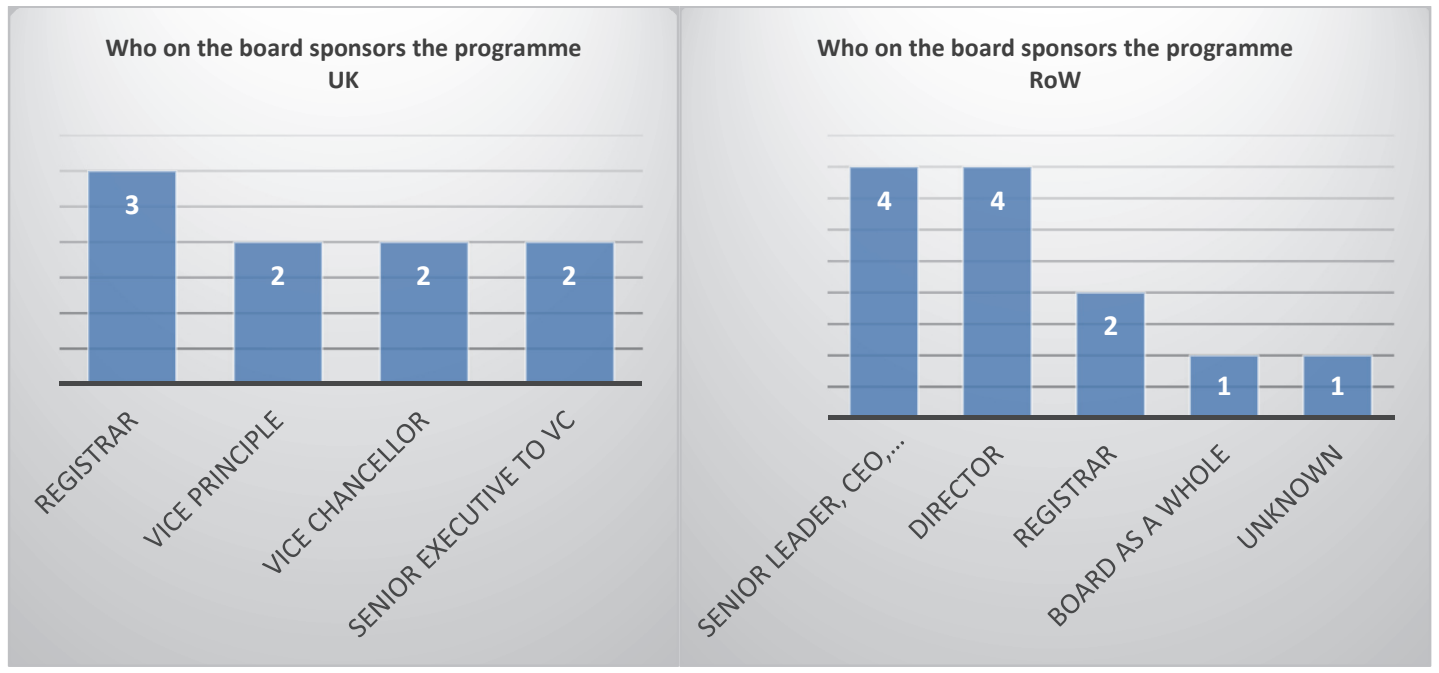

3.9 Question 9: What competencies, knowledge, skills and behaviours within the leadership team of this continuous improvement programme / change agenda were particularly required to guarantee success?

For the UK, 4 respondents identified competencies, knowledge, skills, and behaviours:

- Experienced of managing change

- Running projects

- Reviewing key processes

- Staff on secondments 
For the RoW, 5 respondents identified competencies, knowledge, skills, and behaviours:

- Team working and cross department working

- Data collection and analysis

- Leadership

- Commitment by all parties

- Involvement by the widest audience

- Continuous improvement expertise

3.10 Question 10: How will the institution sustain any gains and success made though this continuous improvement programme / change agenda?

No formal Lean Six Sigma tools or strategies were identified by the UK- however the following was presented by the respondents as methods to maintain the gains achieved:

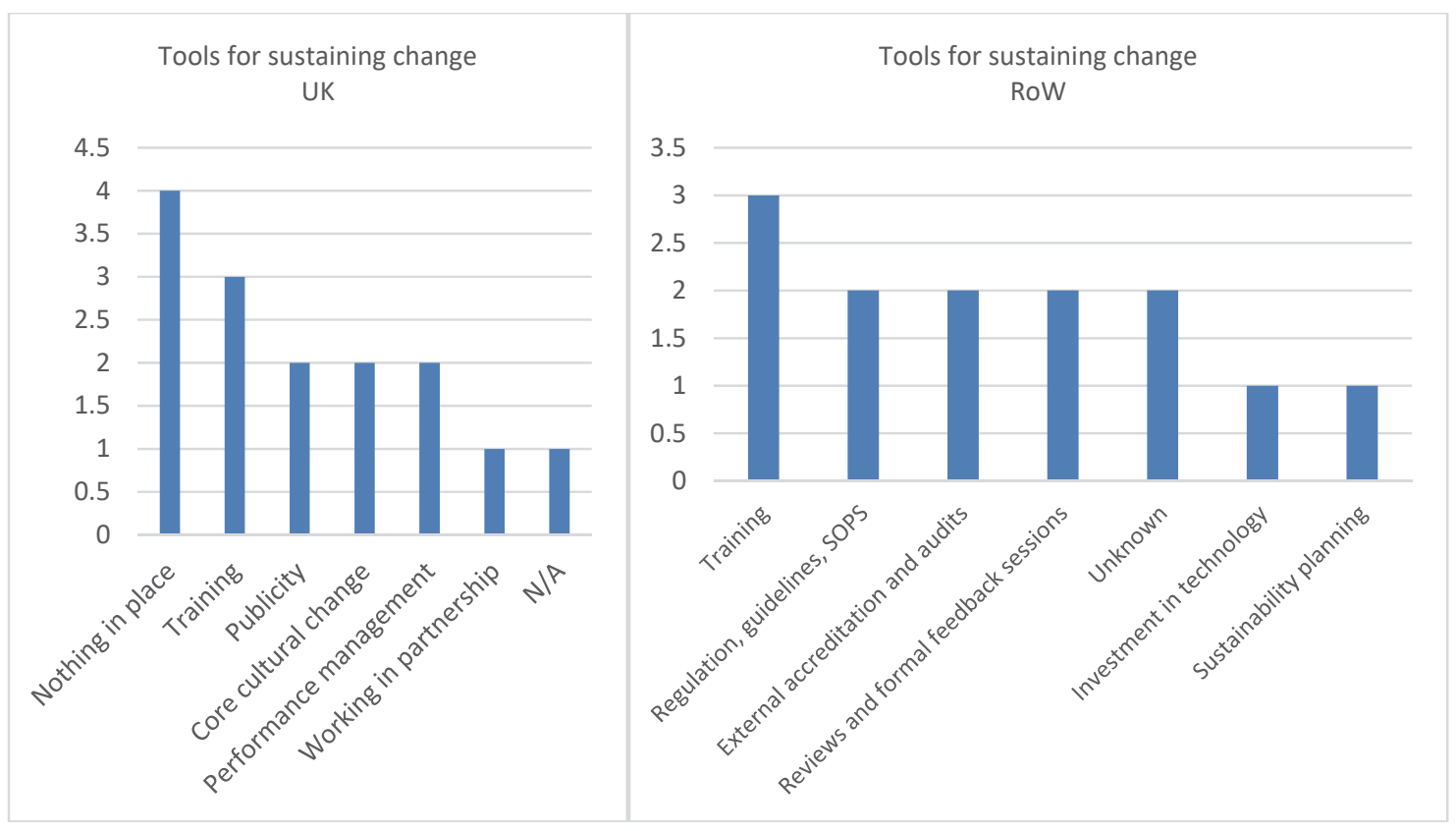

\section{Concluding Comments and Agenda for Future Research}

This study of how universities in the UK and the RoW implement continuous improvement programmes / change agenda has highlighted several interesting trends. The main finding being that UK universities lack maturity in implementing Lean, Six Sigma or Lean Six Sigma philosophies, tools and techniques. This is born out in their understanding of such process excellence methodologies as Lean and Six Sigma, but also in the language used in answering the questions submitted by the author.

This is typical of any new industry or sector embarking on a continuous improvement journey, and it is expected that the level of maturity within these institutions would be significantly less than those of manufacturing industries. However the implementation of Lean Six Sigma is not just about the "destination" but also the "journey" and it is expected that the UK will mature as time progresses. 
The next stage of the research will be to identify several UK and Row institutions for potential case study material. There are several universities in the RoW which have successfully used Lean Six Sigma to improve the operational efficiency and effectiveness beyond the administration processes. They are also examples of UK universities trying to implement Lean Six Sigma beyond the administration processes. It should be possible through detailed study to understand what makes leadership teams in academia successful in implementing Lean Six Sigma. This "maturity" model can then be used by UK academic leaders to assist in a better understanding of the critical success factors around implementing Lean Six Sigma and improve their chances of success and close the gap on the RoW.

There is clearly a need for this model since it appears that academic institutions in the UK have a long way to go before they can truly claim to be Lean, or Six Sigma. One of the main characteristics of Lean Six Sigma is that any business process is open for scrutiny and improvement - teaching and research, not just administration, needs to be embraced before these institutions can claim a Lean Six Sigma status. Finally, the only individuals within an institution who can make this cultural change happen are the leaders, not just of departments, but the ones at the very top of our academic institutions. Such as? Principals in the UK? Vice Principals in the UK? University Presidents in the USA?

\section{References}

Antony Jiju (2014) Readiness factors for the Lean Six Sigma journey in the higher education sector International Journal of Productivity and Performance Management, Volume: 63 Issue: $2,2014$.

Antony Jiju, Krishan Netasha, Cullen Donna, Kumar Maneesh (2012) Lean Six Sigma for higher education institutions (HEIs): Challenges, barriers, success factors, tools/techniques International Journal of Productivity and Performance Management, Volume: 61 Issue: 8, 2012.

Azis Yudi, Osada Hiroshi, (2010) "Innovation in management system by Six Sigma: an empirical study of world-class companies", International Journal of Lean Six Sigma, Vol. 1 Iss: 3, pp.172- 190 .

Bryman A, Barriers to integrating quantitative and qualitative research, Journal of Mixed Methods, Research, 1(1): 8-22, 2007.

Collins, J., (2001) Level 5 Leadership, The Triumph of Humility and Fierce Resolve: Harvard Business Review.

Emiliani ML, Emiliani Michael, (2013) Music as a framework to better understand lean leadership: No407, Leadership and Organisational Development Journal, Vol 34, No. 5 2013, Emerald Group Publishing Limited (2002) Lean Six Sigma - Combining six sigma quality with lean speed, McGraw-Hill, ${ }^{\text {st }}$ Edition, April 25 2002.

Given Lisa (2008), The Sage Encyclopaedia of Qualitative Research Methods, Volume 2, Sage Publications.

Hines Peter, Lethbridge Sarah (2008) New development: Creating a Lean University, Public Money and Management, February 2008.

Heuve Jaap van den, Does Ronald J.M.M, Verver John P.S, (2005) Six Sigma in healthcare: lessons learned from a hospital, Int. J. Six Sigma and Competitive Advantage, Vol. 1, No. 4, 2005 . 
Jenicke Lawrence, Kumar Anil, Holmes Monica, (2008), A framework for applying six sigma improvement methodology in an academic environment, The TQM journal, Vol 20, No5, 2008, pp 453-462.

Joyce Pauline, O’Boyle, Ciaran, (2013) Sustaining academic leadership in higher education, Institute of Leadership Articles, Royal College of Surgeons in Ireland, 1-5-2013.

Kurniawan Agung Widhi and Puspitaningtyas Zarah (2013) Leadership in higher education: academic leader or manager? Buletin Studi Ekonom, Vol 18, No. 1, February 2013. (PP 1-84).

Kumi, S., Morrow, J. 2006. "Improving self service the six sigma way." Newcastle University Library, Vol. 40(2). pp. 123-136.

Laing Linda, Laing, Gregory Kenneth (2011) The student as customer model and its impact on the academic leadership role in higher education, ATN assessment conference 2011 Meeting the challenges.

Loethen Lori, (2008) Six Sigma and Leadership - there is a connection, Quality digest, online articles.

Manville G, Greatbanks R, Krishnasamy R, Parker D (2012), 'Critical success factors for Lean Six Sigma programmes: a view from middle management’ Emerald, Vol: 29 (1), pp: 7-20.

Maleyeff John, Sustaining Public Sector Lean Six Sigma: Perspectives from North America School of Management, Management and Organizational Studies Vol. 1, No. 2; 2014.

Mayo Anthony J, Nohria Nitin, (2005) In their time, the greatest business leaders of the twentieth century: 2005, Harvard Business School Press.

Mehmood Ijaz, Khan Shahinshah Baber, Raziq Khan, Tahirkheli Shaheen Ashraf, (2012) Role of academic leadership in change management for quality in higher education in Pakistan, Journal of education and practice, Vol 3, No16, 2012.

Sakthivel P B (2007) Top management commitment and overall engineering education excellence. TQM Magazine, 2007, Vol. 19 Issue 3, p259-273, 15p. Publisher: Emerald Group Publishing Limited.

Shamandi Elham, Silong Abu Daud, Ismail Ismi Arif, Samah Bahaman Bin Abu, Omar Zohara, (2013) Structural equation modelling test for relationships between selected leadership competencies and effective academic leadership styles, World applied sciences journal, Vol 21, 2013, pp 1566-1576.

Shahmandi Elham, Silong Abu Daud, Ismail Ismi Arif, Samah Bahaman Bin Abu, Othman Jamilah, (2011) Competencies, Roles and Effective Academic Leadership in World Class university, International journal of business administration, Vol 2 No1 February 2011.

Siddique Anam, Aslam Hassan Danial, Khan Mannan, Fatima Urooj (2011) Impact of academic leadership on faculty's motivation and organisational effectiveness in higher education, International journal of business and social science, Vol 2 No8, May 2011.

Snee Ronald D (2007) Managing Six Sigma's most profound change of all: a new way of thinking, ASQ Six Sigma Forum Magazine, Feb 2007; 6,2, pp 41-43.

Snee Ron Hoerl Roger W, (2002) Leading Six Sigma : A Step-by-Step Guide Based on Experience with GE and Other Six Sigma Companies, Hardback| Financial Times (Prentice Hall). 
Radnor, Z. J. (Zoe J.) and Walley, Paul. (2008) Learning to walk before we try to run : adapting Lean for the public sector. Public Money \& Management, Vol.28 (No.1). pp. 13-20. ISSN 0954-0962.

Temponi Cecilia, (2005) "Continuous improvement framework: implications for academia", Quality Assurance in Education, Vol. 13 Iss: 1, pp.17 - 36.

Vogt Paul W. (2010), Data Collection - 4 volumes, Sage Publications. 